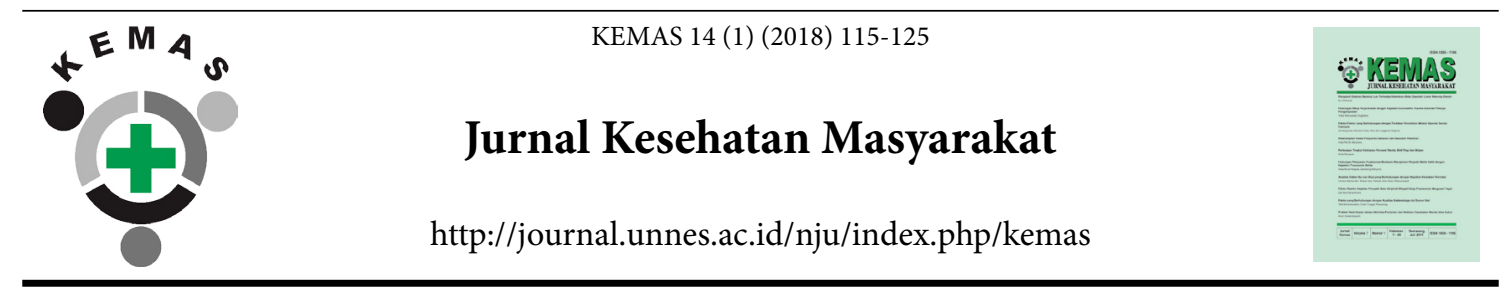

\title{
The Giving of Guava Leaves Boiled Water to Postpartum Perineal Wound Healing
}

\author{
Nina Zuhana ${ }^{1 凶}$ Lia Dwi Prafitri $^{1}$, Wahyu Ersila ${ }^{1}$ \\ ${ }^{1}$ STIKES Muhammadiyah Pekajangan Pekalongan, Indonesia
}

\begin{tabular}{l} 
Article Info \\
\hline Article History: \\
Submitted August 2017 \\
Accepted February 2018 \\
Published July 2018 \\
\hline Keywords: \\
Water Decoction of \\
Guava leaves, Per- \\
ineal Wound Healing \\
\hline DOI \\
https://doi.org/10.15294/ \\
kemas.v14i1.10663
\end{tabular}

\begin{abstract}
Labor often results in a tearing of the birth canal, either primigravida or multigravida with a rigid perineum. Approximately $85 \%$ of women who give birth spontaneously vaginal have $32-33 \%$ perineal trauma due to episiotomy and 52\% are spontaneous lacerations. Perineal trauma may occure perineal infection due to poorly maintained perineal hygiene. This can be prevented by treating injuries. The research aims to know the effect of guava boiled water (psidium guajava linn) on the duration of wound healing of the postpartum nurse's perineum. This research uses quasi-experimental research method with posttes control group design. Population used all postpartum with perineal sew wound in Pekalongan district in 2017 with sampling technique non probability sampling type consecitive sampling. Data analysis using un-paired $t$ test showed that there was influence of guava leaf decoction (Psidium Guajava Linn) on the duration of wound healing of postpartum nurse perineum with significance value p $0,000(<0,05)$.
\end{abstract}

\section{Introduction}

Maternal Mortality Rate (MMR) is one of the sensitive indicators to describe the welfare of people in a country. The maternal mortality referred to the deaths during pregnancy or within 42 days of the end of pregnancy, due to all causes associated with or aggravated by pregnancy or treatment, but not by accident or injury. In 2015, MMR in Central Java Province experienced a significant decrease from 111.16 per 100,000 live births while previously at 126.55 per 100,000 live births in 2014. The highest was brebes with 52 cases and the lowest was temanggung with 3 cases, while the district of Pekalongan showed 22 cases of maternal mortality. $60.9 \%$ of maternal mortality occurred at the time of childbirth, $26.33 \%$ during pregnancy and $12.76 \%$ at the time of delivery. Causes of death were bleeding (21.14\%), hypertension (26.34\%), infections (2.76\%), circulatory system disorders $(9.27 \%)$ and others (40.49\%) (Dinkes Provinsi Jawa Tengah, 2015).

Labor is a series of events that end with giving birth of an adequate or close month infant, followed by expulsion of the placenta and fetal membranes from the mother's body. Labor often results in tearing of the birth canal, either primigravida or multigravida with a rigid perineum (Bick et al., 2010). About 85\% of women who deliver a baby spontaneously the vagina will have $32-33 \%$ perineal trauma due to episiotomy and $52 \%$ due to spontaneous lacerations, and about $3 / 4$ of them require perineal suture to assist the healing (Bick et al., 2010).

\footnotetext{
Correspondence Address:

Jl. Raya pekajangan No.87 Pekalongan 51172, Indonesia.

Email : ninazuhana@gmail.com
}

pISSN 1858-1196

eISSN 2355-3596 
The perineal rupture is a tear that occurs when the baby is born either spontaneously or by means of a device or action. Perineal rupture usually occurs in the midline and can spread if the fetal head come out too soon. Perineal rupture occurs in almost all primiparas (Prawirohardjo, 2007 in Damarini et al., 2013). Perineal rupture may occur due to spontaneous rupture or episiotomy. Most mothers experience a tear in the vagina and perineum giving various amounts of bleeding. Therefore, it requires suturing on the perineum. The healing period of the perineal suture is $7-10$ days and does not more than 14 days. Perineum wound care of the mother after delivery is to reduce discomfort, maintain hygiene, prevent infection and accelerate the healing process. Perineal care is commonly along with vulva treatment. Things should be considered are to prevent rectum contamination, handle the wound tissue carefully, cleans the blood as source of infection and odor (Saifuddin 2001 in Damarini et al., 2013).

Perineal injury either caused by episiotomy or spontaneously teared is difficult area to maintain to be clean and dry all the time, as it is more often to be contaminated with urine or feces. Particular observation and treatment need to be done to ensure the area heals quickly. The vulva cleaning action may provide an opportunity for careful inspection of the perineal area, so the action is expected to accelerate the formation of scar tissue as regular wounds heal in 6 to 7 days (Ma'rifah and Pratiwi, 2015).

In normal labor, along with the rupture, perineal infection may occur due to poorly maintained perineal hygiene. A common cause of over $50 \%$ cases is streptococcus anaerob which is actually not pathogenic as normal birth canal bacteria (Saifuddin, 2014). The symptoms are quite easy to be identified, such as hot and sore on the infected area, sore during urination, fever and the discharge of similar to whitish-mucus with odor smell. During the wound healing process there are factors that can affect the condition of the wound like external factors (environment, tradition, knowledge, socioeconomic, medical handling, mother and nutritional conditions) and internal factors (age, tissue handling, hemorrhage, hypovolaemia, edema local factor, nutrition deficiency, personal hygiene, oxygen deficiency, medication and excessive activity). (Doengoe et al., 1999 in Damarini et al., 2013).

Proper wound care will prevent the infection on the wound of the birth canal, one of the care method that may ease the pain can be done by treating the wound using the bath seat, ie squatting or sitting, then wash the scars with antiseptic fluid ( Doengoe et al., 1999 in Damarini et al., 2013). In addition, Hamilton (2014) explains that perineal wound care can reduce discomfort, improve hygiene and prevent infection by filling plastic bottles with warm water, spray to the perineum then wipe the wound with tissue.

Many herbs have an important role in the treatment and healing of wounds. One of the medicinal plants, known and used by the community is guava plants. Guava leaves contain a variety of phytochemical components that can be used as antioxidants, antidiarrhea, anti-inflammation and anti-dengue fever. Inflammatory compounds in guava leave include essential oils, tannins and flavonoids. This plant is classificated in Myrtaceae family. It grows in the low ground to high ground 1,200 meters above sea level, in loose soil to clay, moreover open areas and lots of water (Nolia et al., 2014).

Based on Guetierrez's research, guava leaf has pectin compound which is a heteropolysaccharide compound and part of human dietary which is water soluble fiber. The main ingredients of pectin are complex glycosides ie D-galactose, L-arabinose and D-xylose so that pectin has potential as antihipercholesterolemia (Beauty, 2015). The function of flavonoids and tannins as antiseptic has very dominant role in protecting wounds from bacterial growth during inflammation and can help in wound healing acceleration (Robinson 1995 in Desiyana et al., 2016). Guava leaf has anti-inflammation effects at doses of $0.77 \mathrm{~g} / \mathrm{kgBW}$ and $1.551 \mathrm{~g} / \mathrm{kgBB}$ due to the presence of flavonoid compounds contained, whereas flavonoid itself has the potential to obstruct cyclooxygenase enzymes so that prostaglandin generation process is inhibited (Lanti et al., 2012)

Other active compound contained in 
guava is tannin. Ministry of Health in 1989 stated that part of the plant oftenly used as medicine is the leaf, as it known to contain 9-12\% tannin compounds, essential oils, fat oil and malic acid (Oktiarni et al., 2012). Fratiwi research result (2015) explains that tannin has properties as spasmolytique effect constricting the intestine so that its peristaltic movement is reduced. Yet, this spasmolytique effect may also be able to constrict the cell wall of bacteria or cell membranes thus disrupting the cell's permeability itself. Due to disruption of permeability, the cell can not perform life activities so that the growth of the cell life is inhibited or even deceased. Tanin also has anti-bacterial power by precipitating protein, because it is suspected tannin has the same effect with phenolic compounds. Antibacterial effects of tannin include reactions with cell membranes, enzyme inactivation, and destruction or inactivation of bacterial genetic material function (Fratiwi, 2015).

According to Kumar (2012) in Desiyana et al. (2016), guava leaf is believed to have astringent effects, wound healing, anti allergies, repair damaged skin, and antimicrobial activity against bacteria that commonly cause infections in surgical and other soft tissue wounds such as Staphylococcus aureus, Steptococcus spp, Escherichia coli, Salmonella typhy, Proteus mirabilis, and Shigella dysenteria. Treatment to obtain these effects also varies, for example the fruit can immediately be eaten, while the leaf should be boiled first. Decoction of guava leaf with various concentrations is known to be able to obstruct the growth of several bacteria strains in opened soft tissue (Juliantoni \& Mufrod, 2013). Desiyana et al., (2016) in the research also obtained the results that the mice given the leaf extract in preparate gel is faster in scab generation and wound healing process. From the above it is important to do research to know The Effect of Guava (Psidium Guajava Linn) Leaves Boiled Water Giving Towards Time of Postpartum Perineal Wound Healing.

\section{Method}

This research uses quasi-experimental research method with post test with control group design, which means in this design there are grouping of control group members and experimental group members to study the effect of guava boiled water (Psidium guajava Linn) to the healing time of postpartum perineal wound. In this study the respondents were divided into two groups namely the intervention group and the control group. The intervention group in this study were respondents who were given guava leaf water (Psidium Guajava Linn), while the control group in this study respondents who were not given boiled water of guava leaf (Psidium Guajava Linn).

The population in this research was all postpartum with perineal suture in Pekalongan district in 2017. By sampling technique in this research is non probability sampling type consecitive sampling obtained 15 respondent for each group which are 15 intervention groups and 15 control groups according to inclusion criteria and did not drop out. The inclusion criteria were the second day postpartum mother who was able to perform personal hygiens independently and volunteerly to be the respondent, parity $<4$, age $<40$ years, normal giving birth process, had second degree perineal suture. While the inclusion criteria were postpartum mothers having diabetes mellitus disease or other diseases that can affect wound healing like keloid and consume antiinflammation drugs.

Data collection technique in this research is by observation; tool to collect data is healing time of perineal wound observation sheet that refers to REEDA scale. Davidson 1974 introduced REEDA (redness, edema, ecchymosis, discharge and approximation) as a tool to assesst perineal wound healing with a score system. Tools and materials to do this research include: 7 sheets of guava leaves, $1 \mathrm{~L}$ boiled water, measuring cup, a plastic bottle with perforated cap, a basin, large nail to perforate bottle cap, plastic and rubber band. Tools used for wound observation include pencil / ballpoint, flashlight, disposable ruler (made of thick paper that has been given millimeter and centimeter mark, used to measure the area and depth of the wound), sterile gloves, sterile gauze.

This research was conducted by identifying postpartum mother who has perineal suture wound then being interventioned by giving guava leaf boiled water every morning, and ask respondent to wash the area 3 times 
a day with guava leaves boiled water until the wound healed. Observation of perineal wound was performed on day 1, 2, 3, 5, 7 and day 10 until the wound was completely healed, dry and there were no signs of infection, the time of healing was recorded on the observation sheet with REEDA scale. The tool used to observe is REEDA observation sheet.

Collected data were classified according to intervention group and control group then tested the normality with Shapiro wilk since the data of each variable was less than 50 respondents. Result of analysis with un-paired $t$ test to indicate the significance of mean difference between intervention group and control group because of normal distributed data.

\section{Result and Discussion}

The data collection process was conducted on March 21 to May 2, 2017 in Pekalongan District. At the time of the research, the numbers of postpartum mothers who meet the inclusion criteria were 30 respondents that consisted of 15 respondents with guava leaf boiled water and clean water wash treatment and 15 respondents became control group with clean water wash treatment only.

The result of this research is analyzed through univariate analysis process which includes respondent characteristics which are age, work, parity and time of wound healing on respondents getting wash treatment with guava leave boiled water and water only followed by bivariate analysis to identify the effect of guava (Psidium Guajava Linn) leaf boiled water giving to time of postpartum perineal wound healing.

On work characteristic, mothers who work in intervention group with guava (Psidium Guajava Linn) leaf boiled water treatment and control group with clean water treatment only were 7 persons $(23.34 \%)$ and do not work 23 persons (76.64\%). The analysis result of the postpartum mother with perineal suture working variable was equivalent or homogeneous with p: $0.171(>0.05)$

On education characteristic, postpartum mothers who have elementary education whice is elementary and junior high school in intervention group with guava (Psidium Guajava Linn) leaf boiled water treatment and control group with clean water treatment only were 21 persons $(70 \%)$ and who have high education which is senior high school and D3 are 9 persons $(30 \%)$. The analysis results of the postpartum mother with perineal suture education characteristic was equivalent or homogeneous with p: $0.238(>0.05)$

On age characteristic, postpartum mothers in the intervention group aged 20-30 years were 11 persons $(73.3 \%)$ and those who $<20$ or $>30$ years were 4 persons $(26.7 \%$ ) while in the control group, thos who aged $20-30$ years

Table1. Respondent Distribution Based on Age, Education, Job and Parity Characteristics in Pekalongan District

\begin{tabular}{|c|c|c|c|c|c|c|c|}
\hline \multirow[t]{2}{*}{$\begin{array}{l}\text { Respondent's } \\
\text { Characteristics }\end{array}$} & \multicolumn{2}{|c|}{$\begin{array}{l}\text { With guava leaf } \\
\text { boiled water }\end{array}$} & \multicolumn{2}{|c|}{$\begin{array}{l}\text { without guava } \\
\text { leaf boiled water }\end{array}$} & \multirow{2}{*}{$\begin{array}{l}\text { Total } \\
\text { numbers }\end{array}$} & \multirow{2}{*}{$\begin{array}{l}\% \\
\text { Total }\end{array}$} & \multirow[t]{2}{*}{$\mathrm{P}$} \\
\hline & Numbers & $\%$ & Numbers & $\%$ & & & \\
\hline Working & 4 & 26.7 & 3 & 20 & 7 & 23.34 & \\
\hline Does not work & 11 & 73.3 & 12 & 80 & 23 & 76.67 & 0.171 \\
\hline Education : & & & & & & & \\
\hline Elementary & 11 & 73.3 & 10 & 66.7 & 21 & 70 & \\
\hline $\begin{array}{l}\text { High School } \\
\text { Age : }\end{array}$ & 4 & 26.7 & 5 & 33.3 & 9 & 30 & 0.238 \\
\hline 20-30 years & 11 & 73.3 & 7 & 46.7 & 18 & 60 & \\
\hline$<20$ and $>30$ & 4 & 26.7 & 8 & 53.3 & 12 & 40 & 0.267 \\
\hline Parity: & & & & & & & \\
\hline $1 \mathrm{x}$ & 4 & 26.7 & 7 & 46.7 & 11 & 36.6 & \\
\hline$>1 \mathrm{x}$ & 11 & 73.3 & 8 & 53.3 & 19 & 63.4 & 0.210 \\
\hline
\end{tabular}

Source: Primary Data, 2017 
Table 2. Frequence Distribution of Postpartum Perineal Wound Healing Time with Guava (Psidium guajava Linn) Leaf Boiled Water Treatment

\begin{tabular}{lllllll}
\hline $\begin{array}{l}\text { Perineal Wound Healing } \\
\text { (days) }\end{array}$ & Frequence & $\begin{array}{l}\text { Percentage } \\
(\%)\end{array}$ & Mean & Median & SD & P \\
\hline 4 & 1 & 6.7 & & & & \\
5 & 8 & 53.3 & 5.47 & 5 & 0.834 & 1.209 \\
6 & 4 & 26.7 & & & & \\
7 & 2 & 13.3 & & & & \\
\hline Total & 15 & 100.0 & & & & \\
\hline
\end{tabular}

Source: Primary Data

were 7 persons $(46.7 \%)$ and those who $<20$ or $>$ 30 years were 8 persons (53.3\%). The result of age variable analysis on postpartum mother who experienced perineal suture wound on intervention group and control group was homogeneous with p value: 0.267 (>0.05).

On parity characteristic, postpartum mother who giving birth for the first time and has perineal suture wound in intervention group were 4 persons (26.7\%) and mother whose parity more than one were 11 persons (73.3\%) while in the control group postpartum mother who giving birth for the first time were 7 persons (46.7\%) and mother whose parity more than one were 8 persons (53.3\%). From analysis result of postpartum mother who had perineal suture wound in intervention group and control group was homogeneous with $\mathrm{p}$ value: $0.210(>0.05)$.

The respondents' characteristics in this study consist of age, parity, education, and job. From respondents four characteristics indicated that there was no significant effect between those who got the guava (Psidium Guajava Linn) leaf water boiled treatment with those who did not (clean water only). Thus it can be concluded that the respondents' characteristics between the groups are equal or homogeneous. This also identifies that the effect of respondent characteristics to postpartum perineal wound healing can be controlled.

Primadona \& Susilowati (2015) in the research stated that the proliferation phase symptom was mostly found on age 20-35 years old which were 27 respondents (60\%) where faster wound healing occurred at young age than old ones. The elderly can not tolerate stress such as tissue trauma or infection. The higher some one education, the easier to accept information, thus the more knowledge owned and vice versa some one with poor education will obstruct the development of someone's attitude to introduced new values. A high education level will assist someone to receive information, thus more knowledge can be obtained, particularly regarding perineal wound care. Mother's knowledge of postpartum care greatly determines the time of perineal wound healing. If the knowledge of the mother is poor, particularly about the matters related with hygiene then wound healing time will be long (Primadona \& Susilowati, 2015).

According to Soekidjo (2002) in Primadona \& Susilowati (2015) experience is the best teacher. Because experience is a source of knowledge or a way to gain the truth. If a person has given birth for the second time and so on generally able to manage well perineal care since they have had experience and information from the previous labor. The work in this case can also affect the postpartum mother during perineal care, where the working mother will be easier to gather information compared to the mother who does not working.

From the analysis result from table 2 it can be seen that $53.3 \%$ respondents given guava (Psidium guajava Linn) leaf boiled water have perineal wound healing time as long as 5 days. The mean of healing time for the postpartum mother having a perineal suture wound and being treated with guava leaf boiled water was 5.47 days with standard deviation of 0.834 . The results of data normality test by Shapiro-wilk obtained p: 1.209 so it can be concluded that the data is normally distributed ( $>0.05)$.

Research results on perineal wound healing showed that $53.3 \%$ of respondents who are treated with guava (Psidium Guajava Linn) leaf boiled water have 5 days healing time. This indicated that the application of guava leaf boiled 
Table 3. Frequence Distribution of Postpartum Perineal Wound Healing Time without Guava Leaf Boiled Water Treatment (Clean Water Only)

\begin{tabular}{|c|c|c|c|c|c|c|}
\hline Perineal Wound & Frequence & Percentage & Mean & Median & SD & $\mathrm{P}$ \\
\hline 7 & 1 & $\frac{(10)}{6,7}$ & 11.13 & 12 & 2.588 & 0.772 \\
\hline 8 & 3 & 20 & & & & \\
\hline 10 & 3 & 20 & & & & \\
\hline 12 & 3 & 20 & & & & \\
\hline 14 & 5 & 33.3 & & & & \\
\hline Total & 15 & 100.0 & & & & \\
\hline
\end{tabular}

Source: Primary Data, 2017

Table 4. Comparation of Postpartum Mother Perineal Wound Healing Treated with Guava Leaf Boiled Water and without Guava Leaf Boiled Water Treatment (Clean Water Only)

\begin{tabular}{lllllll}
\hline Intervention & & $\mathrm{N}$ & $\begin{array}{l}\text { Mean } \\
\text { Difference }\end{array}$ & Lower & Upper & $\mathrm{P}$ \\
\hline $\begin{array}{l}\text { Perineal } \\
\text { wound } \\
\text { healing time }\end{array}$ & $\begin{array}{l}\text { Guava } \\
\text { leaf } \\
\text { boiled } \\
\text { water }\end{array}$ & 15 & -5.667 & -7.104 & -4.229 & .000 \\
& $\begin{array}{l}\text { Clean } \\
\text { water }\end{array}$ & 15 & & & & \\
& & & -7.148 & -4.185 & \\
\hline
\end{tabular}

Source: Primary Data

water as washing media on postpartum mother having perineal suture wound heal faster. Based on Claus and Tyler's research in 1965, tannin has antiseptic effect that prevents the harm caused by bacteria and fungi (Nuryani et al., 2017). One of the guava contents is flavonoids that able to obstruct bleeding by increasing the number of thrombocyte, so that when bleeding occurs in the body, the thrombocyte will be broken out and produce thrombokinase enzyme which will then work as an enzyme to activate the fibrinogen molecule in blood plasma. By then, open wound will dry quickly and stop the bleeding in new wounds (Widjajakusumah, 2002 in Hasibuan et al., 2015). Research Hasibuan et al. (2015) supports this research that guava leaf with water-based solvents are able to assist the healing acceleration on mice indicated by the number of lymphocytes and neutrophils which are near to normal limits as a reference to the well-wound healing process.

In this research, the postpartum mother who washes the perineal suture wound with guava leaf boiled water almost entirely showed no signs of REEDA, this is due to the anticeptic content of guava that prevent the wounds from infection, in addition to the mother's personal hygiene that affect healing process of the wound. This research is aligned with one conducted by Darmawati and Sastra (2013) stated that wound that has REEDA signs are not likely to heal normally and vice versa if the wound does not has REEDA signs would not be obstructed in the process of healing normally.

From the analysis results of table 3 it can be seen that almost half of the respondents or $33.3 \%$ who were not given guava leaf boiled water or only washed with clean water has healing time 14 days. The average time of perineal wound healing on control group respondents using clean water only was 11.13 with standard deviation 2.588 . The results of normality test data obtained sig 0.772 then can be concluded that data distribution was normal $(>0.05)$.

The analysis results by un-paired t test can be done since the data is normally distributed. The significance value obtained was 0.000 $(<0.05)$. Therefore it can be concluded that there is effect of guava (Psidium Guajava Linn) leaf 
boiled water treatment to postpartum perineal wound healing time.

Nearly half of the respondents or $33.3 \%$ who were not treated with guava leaf boiled water or washed by clean water only had average healing time of 14 days. According to Boyle (2008) in Darmawati and Sastra (2013) that open wounds and partial dehiscence or total 6-10 days after surgery are usually related with infection. Factors causing the infection can come from the injury of the birth canal which is a good medium for germs development. This is due to low mother's immunity after giving birth, poor treatment and poor hygiene (BKKBN 2004 in Moloku, 2013).

Poor personal Hygiene (self-hygiene) can obstruct healing process. This can lead to the presence of foreign objects such as dust or germs. According to Cahyati and Lestari (2009) the poor personal hygiene is due to the lack of awareness and knowledge about clean water in addition to the inability to buy tap water as clean water to meet the requirement.

From the results, researchers assume that the time of perineal wound healing on mother who only washes with clean water because of information provided by the health attendant may not be taken properly by the mother. Problems that may occur during the treatment of perineal suture are the fear of the mother to touch the wound, unproper personal hygiene. This is aligned with the research by Divini et al., (2017) that there is relation between perineal wound care and personal hygiene behavior of postpartum patient. Also with Johson's (2005) theory in Divini et al., (2017). Stated that personal hygiene behavior can obstruct as result of foreign objects presence such as dust and germs. The presence of foreign object, extensive tissue exfoliation will obstruct wound healing and causing the strength of the wound strain remains low.

The research by I'anah et al., (2014) mentioned that there are $10 \%$ of postpartum mothers who still have less knowledge regarding personal hiegiene on perineal wound. This is affected by education, job, information and environment, tradition, socioeconomic factors, so that the personal hygiene done by the postpartum mother on the perineal wound will also affect the healing rate and time of the healing process. This is aligned with what researchers do, that the mother knowledge, among others, is influenced by environmental factors and traditions. The postpartum mother assumes that the perineal wound will heal by itself so that the treatment is not so concerned, nor is the condition of the environment and tradition that could be less supportive in the treatment of perineal wound, for example the mother should not wake and leave the bed at night, or the tradition advising that at night it is not allowed to consume water. So that the mother hold urination and it affects the time and the process of wound healing.

According to Smeltzer \& Bare (2009) the time of perineal wound healing cathegory consists of; rapid if the perineal wound is healed within 1-6 days, with a well-closed wound mark, the granulation tissue is not visible, the occurance of minimal scar tissue. Normal if the perineal wound is healed within 7-14 days, with the same sign of rapid healing but longer time span. Long if the healing process takes $\geq 14$ days with the marks of wound edges are not closing, the refinement process is poor, sometimes along with the occurance of pus and a relatively longhealingtime.

The research also showed that wound healing lasted an average of 12 days, but there were 5 respondents who had a healing time of 14 days, the time of this healing process can be caused by several factors such as maternal nutrition that could be a result of protein diet during the postpartum period, and infection where at the time of researchers conduct the observation on perineal wound of the mother who did not wash it with guava leaf boiled water on day 14 saw that edge of wound had not closing and produce typical smell though at observation showed no pus on the wound. This is in aligned with the research conducted by Darmawati \& Sastra (2013) mentioned that nutritional factors, rest, infection, and stress can affect the process of wound healing on postpartum mother who suffered stitches of perineal seams.

The results showed that there was an effect of guava (Psidium Guajava Linn) leaf boiled water on the time of postpartum perineal suture wound healing, with $\mathrm{p}$ value $0.000(<0.05)$. From REEDA observations on 
postpartum perineal suture wound every day showed very significant change. Respondents who used guava leaf boiled water the healing of perineal suture wound were faster than the control group respondents who used water only. The result of this research is supported by Aponno et al., (2014) that gel of guava leaf ethanol extract with concentration variations of $1 \%, 5 \%$ and $7 \%$ had a healing effect on wound infected by Staphylococcus aureus on rabbit. The quickest wound healing was achieved on $5 \%$ concentration rather than $7 \%$, since the concentration of the active ingredient is also an important factor in wound healing.

Based on the theory that mother's selfhygiene helps to reduce infection source and provide comfortable feeling to the mother. To take care and to keep the mother's perineum always clean and dry also clean the genitals front to back will make the wound healing process quick. Personal care or personal hygiene objective is to prevent the risk of infection (Hapsari, 2010 in Divini et al., 2017). According to Divini et al., (2017) it can be seen that there is a considerable comparison between perineal wound care that keep dry and clean all the time with proper behavior and poor behavior with unproper perineal wound care and does not keep dry. Respondents performing perineal wound care that keep it clean and dry and have proper behavior, were highly affected in determining the beliefs and health values also able to determine the correct way to take care the perineal wound.

According to Suwiyoga (2004) in Divini et al., (2017), improper perineal care could lead to perineal conditions affected by lokhea and moisture that will very support the bacteria proliferation that result perineum infection. The infection in the perineum can spread to urinary canal or even birth canal that could result in the complication. Foreign object could be the focus of infection on the wound and if the wound is contaminated by a foreign object or necrotic tissue, wound cleansing is required to prevent the healing slowdown. The dirty wound should be washed to clean, if the wound is dirty, then healing will be difficult, even if it healed it will not result well. So clean wound heal faster than dirty wound (Henderson \& Jones, 2006 in Divini et al., 2017)
The research results by Oktiarni et al., (2012) also showed that the giving of guava leaf extract successfully heal burn wound on mice. The same research by Fernandes et al., (2010) found out that Clinically and histologically, wound on the mice given guava leaf extract healed faster than the group given corticosteroids, so it can be used as a phytotherapy that can contribute in tissue recovery. Desiyana et al., (2016) research supported with result that the content of guava leaf in gel preparat could accelerate the scab generation on mice that had been injured on the back area. Guava leaf content can accelerate the inflammation phase, where on this phase, damaged tissue releases histamine and mast cells that can cause vasodilatation. The vasodilatation leads to increased blood flow and local irritation resulting in redness of the wound. The scab is formed as a protective mechanism for the proliferation phase under. The faster the scab generated, the faster the healing process of the wound.

Based on the research result respondents given guava leaf boiled water heal faster than those who did not, this is because the compound content of guava leaf that can help the wound healing process. Chemical content and chemical properties of guava leaf consist of Tanin, essential oil, Flavonoids, ursolic, Oleanolic, Carotene, Avicularin, Guaijaverin, B1, B2, B3, B6 Vitamin and $\mathrm{C}$ vitamin. The contents of guava leaf are tannin compound 9-12\%, essential oil, fat oil and malic acid (Yuliani et al., 2003 in Nuryani et al., 2017). The benefits of guava (Psidium guajava L.) leaf are proven to accelerate the healing of skin infections commonly caused by Staphylococcus aureus, Streptococcus spp, Escherichia coli, Salmonella typhi, Proteus mirabilis, and Shigella dysenteria (Desiyana et al., 2016). Guava leaf extract is obtained by maceration using ethanol solution. The ethanol concentration used affects the amount of tannin in the extract. According to Erfan Yudapraja (2012) 70\% ethanol content attracts more tannin and is the optimal concentration to gain yield (Aponno et al., 2014).

Psidium guajava L. is known to contain several active ingredients such as tannin, flavonoid, guayaverin, leukocyanidin, essential oils, malic acid, resin, and oxalic acid (Fratiwi, 
2015). Essential oils can obstruct the growth of certain types of harmful bacteria such as Escherichia coli, Salmonella sp, Staphylococcus aureus, Klebsiella and pasteurella. In the guava leaf there are also substances like saponin which is suspected help in the generation of kollagen, a protein structures that play a role in the process of wound healing. Other compound play a role as antiseptic is polyphenol. Based on research conducted by John et al., (2008), one of the active ingredients contained in guava leaf is flavonoid that serves as an anti-inflammatory active compound, reducing pain, anti-tumor, HIV antiviral, antidiarrhea, liver anti-toxic, anti fungi, anti-oxidants, prevent the constriction of blood vessels, stimulate immunity and skin anti-itchy.

According to Daudet al., (2011) in Rabbaniyah Research (2015), guavaleafcontains flavonoid, tannin (17.4\%), phenolics (573.3 mg / g), and essential oils. The pharmacological effects of this leaf are anti-inflammatory, antidiare, analgesic, antibacterial, antidiabetic, antihypertensi, and platelet enhancer. One of the flavonoid compounds contained in guava leaves is quersetin which has a boiling point of 310 OC so quersetin is resistant to heat. Guava leaf has been widely used in traditional medicine. Empirically guava leaf is antibiotic and has been used for antidiarrheal.

According to Oktiarni et al., (2012) guava leaf contains saponin that has characteristic similar to foam. Therefore when it is reacted with water, will form a long-lasting froth. Rabbaniyah (2015) said that saponin has pain relieving effect and stimulate new cells generation. Wound healing has positive correlation with reepitalization process, because the faster reepitalization process the faster wound healing process. This is indicated at the observation of perineal suture wound on patient who washed/wiped the perineal wound with guava leaf boiled water had a relatively quick healing time which was 5 days, whereas mother who washed with clean water only had average healing time on day 12 . Based on the finding when visited the postpartum patients who wash wounds with guava leaf boiled water communicated comfortable feeling and painless on the wound after washing it with guava leaf water boiled.
The results of Dina's research (2010) in Divini et al., (2017) said there is relation between personal hygiene and perineal wound care because most of the respondents in Health Clinic Harapan Ibu already know how to care the wound such as how to keep the wound clean and dry. This is also aligned with the theory by Johson (2005) in Divini et al., (2017) that personal hygiene behavior can slow the healing caused by foreign objects such as dust and germs. The presence of foreign object, extensive tissue exfoliation will slow wound healing and the strength of the wound strain remains low.

Perineal infections can be avoided and even healing process can be accelerated when treatment is done properly and appropriately, fail to treat so can be disadvantageous to the patient. Perineal pain is a significant source of problem for many women after giving birth, not only in postpartum period but also for long time after. Post-episiotomy wound should be treated properly so that the wound heals quickly and no infection occured. The causes of perineal infection are Streptococcus haemoliticus, Staphylococcus aureus and Escherichia coli. For that, proper technique is needed in wound care, and the most important thing is the correct use of material. This is very important since if the material usage is not correct, it can be difficult to heal and may result of infection. The health attendant must understand the physiology of wound healing and should be able to assess the wound based on knowledge of skin integrity and infection prevention (Bago, 2011 in Damarini et al., 2013).

The close monitoring efforts and well maternal and infant care during postpartum period are expected to prevent the occurrence of above (BKKBN, 2006 in Divini et al., 2017). Personal hygiene behavior or self sanitation is an individual health effort to be able to maintain personal health, improve and enhance health values and prevent disease. Personal hygiene consists of body hygiene, hands, skin/nails, teeth and hair (Wijaya, 2011 in Divini et al., 2017). When those are not conducted properly, it will generate the risk of postpartum infections due to perineal wound, laceration of the genital canal including the perineum, vaginal wall and cervix.

According to Brunner and Suddarth 
(2001) in Kurnia (2007), there are two factors that affect the healing of a wound which are internal and external factors. Internal factors include wound healing phase and body immunity system. External factors include nutrition, treatment applied, hygiene care considering episiotomy wound is in the perineum area, where it lies between the urinary canal, vagina and anus while the condition of the respondent who is in postpartum period and the lochia is still come out (Pilliteri, 1999 in Kurnia , 2007).

\section{Conclusion}

$53.3 \%$ of respondents who were given guava (Psidium Guajava Linn) leaf boiled water had 5 days perineal wound healing time. 33.3\% of respondents who were not given and wash the perineal wound by clean water only had 14 days perineal wound healing time. There is effect of guava (Psidium Guajava Linn) leaf boiled water giving on the time of postpartum perineal wound healing with signification value p $0.000(<0.05)$.

For health attendance, particularly midwive should be able to provide information to postpartum mother regarding vaginal hygiene evenmore to the mother that has a perineal suture so that the infection caused by germs and microorganisms can be avoided. The results of this research should be used as an alternative way to accelerate healing time of postpartum perineal suture wound, so there should be detailed information about the benefit of guava leaf boiled water for perineal wound healing to the community. For health office, this research should be considered to be socialized to all community health service centre (Puskesmas) in the local area regarding the benefit, thus reducing maternal mortality caused by infection.

\section{Acknowledgement}

The author would like to gratitude to the Ministry of Research, Technology and Higher Education who has provided input, direction and guidance, as well as become the funders in this research. Also to LPPM STIKES Muhammadiyah Pekajangan Pekalongan which has been greatly support for this research.

\section{References}

Aponno, J.V., Yamlean, P.V.Y., \& Supriati, H.S., 2014.

Uji Efektivitas Sediaan Gel Ekstrak Etanol
Daun Jambu Biji (Psidium guajava linn) Terhadap Penyembuhan Luka yang Terinfeksi Bakteri Staphylococcus Aureus Pada Kelinci (Orytolagus cuniculus). Pharmacon, Jurnal Ilmiah Farmasi Unsrat, 3(3), pp.279-286.

Beauty, B.A., 2015. Guava Leav Extract (Psidium guajava Linn) As a Hypercholesterolemia Treatment. Journal Majority, 4(3), pp.29-33.

Bick, D.E., Kettle, C., Macdonald, S., Thomas, PW., Hills, RK., \& Ismail, K.M.K., 2010. Perineal Assessment and Repair Longitudinal Study (PEARLS): Protocol for A Matched Pair Cluster Trial. BMC Pregnancy and Childbirth, 10(10), pp.1-8.

Cahyati, W.H., \& Lestari, F., 2009. Hubungan Kebersihan Pribadi dan Riwayat Luka dengan Kejadian Leptospirosis. Jurnal Kesehatan Masyarakat, 5(1), pp.70-79.

Damarini, S., Eliana, \& Mariati., 2013. Efektivitas Sirih Merah dalam Perawatan Luka Perineum di Bidan Praktik Mandiri. Jurnal Kesehatan Masyarakat Nasional, 8(1), pp.39-44.

Darmawati, \& Sastra, I., 2013. Hubungan FaktorFaktor Yang Mempengaruhi Penyembuhan Luka Dengan Lama Penyembuhan Luka Perineum Ibu Nifas. Idea Nursing Journal, II(3), pp.41-51.

Desiyana, L.S., Husni, M.A., \& Zhafira, S., 2016. Uji Efektivitas Sediaan Gel fraksi Etil Asetat Daun Jambu Biji (Psidium guajava Linn) terhadap Penyembuhan Luka Terbuka pada Mencit (Mus musculus). Jurnal Natural, 16(2), pp.23-32.

Dinkes Provinsi Jawa Tengah. 2015. Profil kesehatan Provinsi jawa Tengah Tahun 2015. Dinkes Prov. Jateng.

Divini, V.P.T., Kundre, R., \& Bataha, Y., 2017. Hubungan Perawatan Luka Perineum dengan Perilaku Personal Hygiene Ibu Post Partum di Rumah Sakit Pancaran Kasih GMIM Manado. e-Journal Keperawatan (eKp), 5(1), pp.1-9.

Fernandes, K.P.S., Sandra, K.B., Marcia, M.M., Nisa, S., Yamashita, W., Erna, B., Manoela, D.M., 2010. Healing and Cytotoxic Effects of Psidium guajava (Myrtaceae) Leaf Extracts. Braz Journal Oral Sci, 9(4), pp.449-454.

Fratiwi, Y., 2015. The Potential of Guava Leaf (Psidium guajava L.) For Diarrhea. Journal Majority, 4(1), pp.113-118.

Hamilton, P.M., 2014. Dasar-dasar Keperawatan Maternitas Edisi 6. EGC: Jakarta.

Hasibuan, F.N., Yuniwarti, E.Y.W., \& Suedy, S.W.A., 2015. Effect of Psidium guajava Linn. Leaves and Anacardium Occidentale Linn on wound healing to Mus musculus Linn skin. 
Traditional Medicine Journal, 20(1), pp.2427.

I’anah, S., Taadi., Hartono, M., Supriyo., 2014. Hubungan Antara Pengetahuan Ibu Nifas Tentang Personal Hygiene Pada Luka Perineum Dengan Penyembuhan Luka Fase Proliferasi Di Wilayah Kerja Puskesmas Jenggot Kota Pekalongan. Pena Jurnal Ilmu Pengetahuan Dan Teknologi, 26(2), pp.156170.

John, A.O.O., Emmanuel, O.A., \& Witness, D.H.C., 2008. Antidiarrhoeal activity of Psidium guajava L. Linn. (Myrtaceae) Leaf Aqueous Extract in Rodents. Journal Smooth Muscle Res, 44(6), pp.195-207.

Juliantoni, Y., \& Mufrod, 2013. Formulasi Tablet Hisap Ekstrak Daun Jambu Biji (Psidium guajava L.) yang Mengandung Flavonoid Dengan Kombinasi Bahan Pengisi ManitolSukrosa. Traditional Medicine Journal, 18(2), pp.103-108.

Kurnia, N.S., 2007. Pengaruh Pendidikan Kesehatan tentang Perawatan Perineum terhadap Kesembuhan Luka Episiotomi Klien Post Partum Partum di BKIA Aisyiyah, Karangkajen, DIY. Jurnal Mutiara Medika, 7(1), pp.1-6.

Lanti, D., Fatimawali, Wullur, A., 2012. Uji Efek Antiinflamasi Ekstrak Etanol Kulit Batang Jambu Biji (Psidium Guajava) Terhadap Edema Kaki Tikus Jantan Galur Wistar. Pharmacon, Jurnal Ilmiah Farmasi Unsrat, 1(2), pp.119-125.

Ma'rifah, A., \& Pratiwi, Y.D. 2015. Hubungan Perawatan Luka Perineum Pada Ibu Nifas Dengan Lama Penyembuhan Luka Jahitan Perineum Ibu Nifas Diruang Lingkup BPM Sanadah, SST Mojogeneng Mojokerto. Jurnal
Keperawatan Bina Sehat, 12(2), pp.1-6.

Moloku, F., 2013. Hubungan Pengetahuan tentang Perawatan dengan Penyembuhan Luka Episiotomy pada Ibu post partum di Ruangan IRINA D bawah RSUP Prof. Dr. R. D. Kandau Malalayang. ejournal Keperawatan (e-Kp), 1(1), pp.1-5.

Nolia, W.D., Nursyahra, \& Fitriani, V., 2014. Uji Sari Daun Jambu Biji (Psidium guajava L.) Terhadap Pertumbuhan Bakteri Escherechia coli. Jurnal Pendidikan Biologi, 4(2).

Nuryani, S., Saptono, R.F.P., \& Darwani, 2017. Pemanfaatan Ekstrak Daun Jambu Biji (Psidium guajava Linn) Sebagai Antibakteri dan Antifungi. Jurnal Teknologi Laboratorium, 6(2), pp.41-45.

Oktiarni, D., Manaf, S., Suripno, 2012. Pengujian Ekstrak Daun Jambu Biji (Psidium guajava Linn) terhadap Penyembuhan Luka Bakar pada Mencit. Jurnal Gradien, 8(1), pp.752755.

Primadona, P., \& Susilowati, D., 2015. Penyembuhan Luka Perineum Fase Proliferasi Pada Ibu Nifas. Jurnal Profesi, 13(1), pp.1-5.

Rabbaniyah, F., 2015. Pengaruh Pemberian Ekstrak Daun Jambu Biji (Psidium guajava Linn) terhadap Peningkatan Trombosit pada Pasien Demam Berdarah Dengue. Jurnal Majority, 4(7), pp.91-96.

Saifuddin, A.B., 2014. Ilmu Kebidanan. Bina Pustaka Sarwono Prawirohardjo: Jakarta.

Smeltzer, S.C., \& Bare, B.G., 2009. Buku Ajar Keperawatan Medikal Bedah Brunner \& Suddarth (Edisi 8 Volume 1). EGC: Jakarta. 